\title{
Genetic Differentiation among Nigerian Indigenous Goat Populations
}

\author{
O. A. Ojo ${ }^{1}$, G. N. Akpa ${ }^{2}$, M. Orunmuyi ${ }^{2} \&$ I. A. Adeyinka ${ }^{3}$ \\ ${ }^{1}$ National Agricultural Extension and Research Liaison Services, Ahmadu Bello University, Zaria, Kaduna State, \\ Nigeria \\ ${ }^{2}$ Department of Animal Science, Ahmadu Bello University, Zaria, Kaduna State, Nigeria \\ ${ }^{3}$ National Animal Production Research Institute, Ahmadu Bello University, Zaria, Kaduna State, Nigeria \\ Correspondence: O. A. Ojo, National Agricultural Extension and Research Liaison Services, Ahmadu Bello \\ University, Zaria, Kaduna State, Nigeria. E-mail: kemiojo20@gmail.com
}

Received: June 1, 2015 Accepted: July 9, 2015 Online Published: October 15, 2015

doi:10.5539/jas.v7n11p39 URL: http://dx.doi.org/10.5539/jas.v7n11p39

\begin{abstract}
A total of 200 goats and 25 microsatellite markers proposed by the Food and Agricultural Organization and the International Society for Animal Genetics (FAO-ISAG) were used to determine the genetic diversity of three breeds of the Nigerian indigenous goats, namely Sahel (60), Red Sokoto (60), West African Dwarf (60) and one strain; Kano Brown (20). Genetic differentiation between the breeds and strain ranged from 0.011 to 0.037, and the least genetically differentiated populations were Kano Brown and Red Sokoto. Molecular variations were observed to be higher within populations (96\%) than among populations $(4 \%)$, which suggest higher heterozygosity within populations. This study showed that the Nigerian goats are admixed due to extensive cross-breeding and high gene flow amongst the breeds, and that the goats are geographically distributed in two major locations. Measures to conserve the uniqueness/distinctiveness of the Nigerian goat breeds should be sought, and gene flow between populations should be controlled by adopting effective breeding and management practices.
\end{abstract}

Keywords: Nigerian indigenous goats, microsatellite markers, molecular variation, gene flow

\section{Introduction}

Goat is one of the world's most adaptable and widespread livestock species, and contributes largely to the main economic resources in many developing countries including Nigeria. Their economic importance is growing in western countries (Luikart et al., 2001). Goats constitute the largest group of small ruminant livestock in Nigeria totaling about 53.8 million; and constitute $6.2 \%$ of the world's goat population (FAOSTAT, 2011).

Genetic variation between and within breed is described as diversity and it is a valuable asset as the adaptability of a population, depends on it (Woolliams et al., 2005). It is well known that species can face great environmental changes over time, such as in climate, pollution and disease; and genetic diversity is required for populations to adapt to these changes (Frankham et al., 2002).

If genetic diversity is very low, none of the individuals in the population may have the characteristics needed to cope with the new environmental conditions or challenge. Such a population could be suddenly wiped out. Also, low genetic diversity increases the vulnerability of populations to catastrophic events such as disease outbreaks. Loss of genetic diversity is often associated with inbreeding, selection, gene flow and migration (Frankham et al., 2002; Willi et al., 2006).

This study therefore, attempted to analyze the diversity of four Nigerian indigenous goat populations namely, Sahel, Red Sokoto, Kano Brown and West African Dwarf using twenty-five microsatellites as molecular markers.

The objectives of this study are to:

$>$ Evaluate the genetic differences between the Nigerian goat populations;

$>$ Determine the extent of gene flow between the goat populations. 


\section{Materials and Methods}

\subsection{Study Location}

This study was carried out using four goat populations namely; Sahel, Red Sokoto, Kano Brown and West African Dwarf goats in three states of the country namely, Jigawa, Kaduna and Oyo State. The Sahel goats were sourced from Maigatari International market of Jigawa state. Maigatari is a district in Jigawa state, with an average elevation of 352 meters above sea level. The town is mildly densely populated with 148 people per $\mathrm{km}^{2}$ and a total population of 7,799 people. Its coordinates are $12^{\circ} 48^{\prime} 26^{\prime \prime} \mathrm{N}$ and $9^{\circ} 25^{\prime} 5^{\prime \prime} \mathrm{E}$. The average annual temperature is $27.3{ }^{\circ} \mathrm{C}$ with an average rainfall of about $418 \mathrm{~mm}$ per annum. Maigatari is semi arid in nature and the soil is very sandy (Ibrahim et al., 2012).

The Red Sokoto and Kano Brown goats were sourced from the Teaching and Research farm of the Department of Animal Science, Ahmadu Bello University, Zaria. The Teaching and Research Farm of the University is located in the Northern Guinea Savannah zone of Nigeria. It receives a mean precipitation of $1,107 \mathrm{~mm}$ per annum, which stretches over 120-170 days from late April to early September (Issa et al., 2011). Seasonal distribution of rainfall is approximately $0.1 \%$, late dry (January-March), $25.8 \%$ early wet (April-June) $69.6 \%$ late wet (July-September) and $4.5 \%$, early dry (October-December) season. Average maximum temperature is $38.89^{\circ} \mathrm{C}$ while the average minimum ambient temperature is $8.89^{\circ} \mathrm{C}$ and the yearly average for the past 7 years is $25.55^{\circ} \mathrm{C}$ (Issa et al., 2011). The mean relative humidity during dry and wet seasons is 21 and $72 \%$ respectively. Good quality forage is more abundant in the late wet and early dry seasons while forages are generally scarce and very low in quality during late dry and early wet seasons (Akpa et al., 2002).

The West African Dwarf goats were sourced from the Bodija Abattoir at Ibadan, Oyo state. Bodija has latitude of 7.436 and longitude of 3.919, its elevation ranges from $150 \mathrm{~m}$ to $275 \mathrm{~m}$ above sea level. Its temperature ranges from $21.15^{\circ} \mathrm{C}$ to $34.8^{\circ} \mathrm{C}$ with a mean of $26.6^{\circ} \mathrm{C}$. The wet season spans from March through October. There are two peaks of rainfall, June and September while the least is in January and December. The mean annual rainfall is $1,258.9 \mathrm{~mm}$ with a relative humidity of $94 \%$. November to February forms the city's dry season (Cadmus et al., 2008).

\subsection{Experimental Animals}

A total of 200 randomly sampled indigenous goats from three (3) breeds namely: Sahel (60), Red-Sokoto (60) and West-African Dwarf goat (60) and one strain; Kano Brown (20). For each breed, a maximum of sixty (60) animals was sampled and twenty (20) for the Kano Brown goats. Tissue samples were collected from the ears of these goats using an Allflex ${ }^{\circledR}$ ear punch tissue sample collector, and aliquoted into plastic tubes containing the Allflex ${ }^{\circledR}$ tissue preservative.

\subsection{Isolation of Genomic DNA from Tissue}

DNA extraction, amplification and sequencing were carried out at the International Livestock Research Institute, (ILRI) Nairobi, Kenya. DNA was extracted from the tissue cells using commercial Kits (Pure Link ${ }^{\text {TM }}$ Genomic DNA Mini Kits for purification of genomic DNA with Catalog numbers K1820-01, K1820-02) according to the manufacturer's specifications and protocol.

\subsection{Polymerase Chain Reaction (PCR)}

A master mix was prepared containing water, buffer, dNTP's, primers and TaqDNA polymerase in a single tube and later aliquoted into individual tubes. Magnesium Chloride $\left(\mathrm{MgCl}_{2}\right)$ and template DNA solutions were then added. The sample was gently vortexed and briefly centrifuged to collect all drops from the walls of the tube. The samples were placed in a thermo cycler using the following settings: an initial denaturation at $95{ }^{\circ} \mathrm{C}(4$ minutes), annealing at $50{ }^{\circ} \mathrm{C}$ ( 45 seconds) and extension at $72{ }^{\circ} \mathrm{C}$ ( 15 minutes) for 35 cycles.

After amplification, the PCR products were run on a $1.5 \%$ agarose gel electrophoresis, stained with Red dye and visualized by ultra-violet light. Bands of the correct size were excised from the gel, documented and sequenced. Twenty five microsatellite markers were used to genotype and were randomly chosen from FAO recommended list as seen in Table 1 . The annealing temperature of the primers ranged between $50^{\circ} \mathrm{C}$ to $65^{\circ} \mathrm{C}$. 
Table 1. Characteristics of microsatellite markers (Primers) used for the study (FAO/ISAG, 2011)

\begin{tabular}{|c|c|c|c|c|c|c|c|}
\hline & Marker & Sequences $\left(F / R: 5^{\prime} \rightarrow 3^{\prime}\right)$ & Annealing ${ }^{\circ} \mathrm{C}$ & Rang & (bp) & Dye & GeneBank Access \\
\hline 1 & SRCRSP03 & $\begin{array}{l}\text { CGGGGATCTGTTCTATGAAC } \\
\text { TGATTAGCTGGCTGAATGTCC }\end{array}$ & 55 & 98 & 122 & NED & L22195 \\
\hline 2 & ILSTS005 & $\begin{array}{l}\text { GGAAGCAATTGAAATCTATAGCC } \\
\text { TGTTCTGTGAGTTTGTAAGC }\end{array}$ & 55 & 172 & 218 & VIC & L23481 \\
\hline 3 & SPS113 & $\begin{array}{l}\text { CCTCCACACAGGCTTCTCTGACTT } \\
\text { CCTAACTTGCTTGAGTTATTGCCC }\end{array}$ & 58 & 134 & 158 & 6FAM & - \\
\hline 4 & CSRD247 & $\begin{array}{l}\text { GGACTTGCCAGAACTCTGCAAT } \\
\text { CACTGTGGTTTGTATTAGTCAGG }\end{array}$ & 58 & 220 & 247 & PET & - \\
\hline 5 & MAF209 & $\begin{array}{l}\text { GATCACAAAAAGTTGGATACAACCGTG } \\
\text { TCATGCACTTAAGTATGTAGGATGCTG }\end{array}$ & 55 & 100 & 104 & VIC & M80358 \\
\hline 6 & McM527 & $\begin{array}{l}\text { GTCCATTGCCTCAAATCAATTC } \\
\text { AAACCACTTGACTACTCCCCAA }\end{array}$ & 58 & 165 & 187 & VIC & L34277 \\
\hline 7 & SRCRSP5 & $\begin{array}{l}\text { GGACTCTACCAACTGAGCTACAAG } \\
\text { TGAAATGAAGCTAAAGCAATGC }\end{array}$ & 55 & 156 & 178 & PET & L22197 \\
\hline 8 & ILSTS087 & $\begin{array}{l}\text { AGCAGACATGATGACTCAGC } \\
\text { CTGCCTCTTTTCTTGAGAG }\end{array}$ & 58 & 135 & 178 & NED & L37279 \\
\hline 9 & SRCRSP9 & $\begin{array}{l}\text { AGAGGATCTGGAAATGGAATC } \\
\text { GCACTCTTTTCAGCCCTAATG }\end{array}$ & 58 & 99 & 135 & PET & L22200 \\
\hline 10 & OarFCB 304 & $\begin{array}{l}\text { CCCTAGGAGCTTTCAATAAAGAATCG } \\
\text { GCGCTGCTGTCAACTGGGTCAGGG }\end{array}$ & 56 & 150 & 188 & - & L01535 \\
\hline 11 & ILSTS11 & $\begin{array}{l}\text { GCTTGCTACATGGAAAGTGC } \\
\text { CTAAAATGCAGAGCCCTACC }\end{array}$ & 58 & 250 & 300 & $6 \mathrm{FAM}$ & L23481 \\
\hline 12 & ETH10 & $\begin{array}{l}\text { GTTCAGGACTGGCCCTGCTAACA } \\
\text { CCTCCAGCCCACTTTCTCTTCTC }\end{array}$ & 55 & 200 & 210 & PET & Z22739 \\
\hline 13 & MAF065 & $\begin{array}{l}\text { AAAGGCCAGAGTATGCAATTAGGAG } \\
\text { CCACTCCTCCTGAGAATATAACATG }\end{array}$ & 58 & 116 & 158 & VIC & M67437 \\
\hline 14 & OarCP34 & $\begin{array}{l}\text { GCTGAACAATGTGATATGTTCAGG } \\
\text { GGGACAATACTGTCTTAGATGCTGC }\end{array}$ & 50 & 112 & 130 & - & U15699 \\
\hline 15 & ILSTS029 & $\begin{array}{l}\text { TGTTTTGATGGAACACAG } \\
\text { TGGATTTAGACCAGGGTTGG }\end{array}$ & 55 & 148 & 170 & NED & L37252 \\
\hline 16 & INRA023 & $\begin{array}{l}\text { GAGTAGAGCTACAAGATAAACTTC } \\
\text { TAACTACAGGGTGTTAGATGAACT }\end{array}$ & 58 & 196 & 215 & NED & X80215 \\
\hline 17 & MAF70 & $\begin{array}{l}\text { CACGGAGTCACAAAGAGTCAGACC } \\
\text { GCAGGACTCTACGGGGCCTTTGC }\end{array}$ & 65 & 134 & 168 & 6FAM & M77199 \\
\hline 18 & INRA063 & $\begin{array}{l}\text { GACCACAAAGGGATTTGCACAAGC } \\
\text { AAACCACAGAAATGCTTGGAAG }\end{array}$ & 58 & 164 & 186 & VIC & X71507 \\
\hline 19 & BM6444 & $\begin{array}{l}\text { CTCTGGGTACAACACTGAGTCC } \\
\text { TAGAGAGTTTCCCTGTCCATCC }\end{array}$ & 65 & 118 & 200 & $6 \mathrm{FAM}$ & G18444 \\
\hline 20 & OarFCB48 & $\begin{array}{l}\text { GAGTTAGTACAAGGATGACAAGAGGCAC } \\
\text { GACTCTAGAGGATCGCAAAGAACCAG }\end{array}$ & 58 & 149 & 173 & PET & M82875 \\
\hline 21 & INRABERN172 & $\begin{array}{l}\text { CCACTTCCCTGTATCCTCCT } \\
\text { GGTGCTCCCATTGTGTAGAC }\end{array}$ & 58 & 234 & 256 & PET & - \\
\hline 22 & INRABERN185 & $\begin{array}{l}\text { CAATCTTGCTCCCACTATGC } \\
\text { CTCCTAAAACACTCCCACACTA }\end{array}$ & 55 & 261 & 289 & PET & X73937 \\
\hline 23 & TCRVB6 & $\begin{array}{l}\text { GAGTCCTCAGCAAGCAGGTC } \\
\text { CCAGGAATTGGATCACACCT }\end{array}$ & 55 & 217 & 255 & PET & L18953 \\
\hline 24 & SRYM18 & $\begin{array}{l}\text { GGCATCACAAACAGGATCAGCAAT } \\
\text { GTGATGGCAGTTCTCACAATCTCCT }\end{array}$ & 58 & 80 & 170 & 6Fam & Y chromosome \\
\hline 25 & OarFCB20 & $\begin{array}{l}\text { GGAAAACCCCCATATATACCTATAC } \\
\text { AAATGTGTTTAAGATTCCATACATGTG }\end{array}$ & 58 & 93 & 112 & VIC & L20004 \\
\hline
\end{tabular}




\subsection{Statistical Analysis}

Gene diversity $\left(\mathrm{F}_{\mathrm{st}}\right)$ and gene flow $(\mathrm{Nm})$ were estimated using the computer software program GenAlex 6.5 (Peakall and Smouse, 2012). Analysis of molecular variance (AMOVA) was performed to quantify further the extent of population differentiation and the distribution of genetic variation in the sampled populations. It was analyzed using GenAlEX 6.5 genetic analysis statistical package (Peakall \& Smouse, 2012).

The Evano-graph and population structure were estimated using the program STRUCTURE 2.0 (Pritchard et al., 2000).

\section{Results}

\subsection{Characteristics of Microsatellite DNA Markers}

A detailed description of the twenty five microsatellite markers and their sequences are presented in Table 1, the annealing temperature ranged between $50^{\circ} \mathrm{C}$ to $65^{\circ} \mathrm{C}$, the most commonly used dye was PET.

\subsection{Pair-Wise Population Genetic Differentiation $\left(F_{s t}\right)$}

Table 2 shows the pair-wise genetic differentiation values $\left(\mathrm{F}_{\mathrm{st}}\right)$, the values ranged from 0.011 to 0.037 . The least genetically different population was between Kano Brown and Red Sokoto (0.011), while the highest genetically different population was between West African Dwarf and Red Sokoto ( 0.037$)$. Per pair $\mathrm{F}_{\mathrm{st}}$ value of 0.05 indicates moderate differentiation and those lower than 0.05 indicates low differentiation between populations/breeds (Hartl, 1980).

Table 2. Gene differentiation $\left(\mathrm{F}_{\mathrm{st}}\right)$ values

\begin{tabular}{lllll}
\hline Populations & RS & KB & SH & WD \\
\hline RS & & & & \\
KB & 0.011 & & & \\
SH & 0.026 & 0.019 & & \\
WD & 0.037 & 0.036 & 0.017 & \\
\hline
\end{tabular}

Note. $\mathrm{RS}=$ Red Sokoto; $\mathrm{KB}=$ Kano Brown; $\mathrm{SH}=$ Sahel; $\mathrm{WD}=$ West-African Dwarf.

\subsection{Analysis of Molecular Variance (AMOVA) of the Nigerian Goat Populations}

In order to understand the partitioning of the level of genetic diversity of the Nigerian goats, an analysis of variance was performed as shown in Table 3 . The results revealed that $96 \%$ of the total genetic variability occurred within individuals in the population, while $4 \%$ of them occurred amongst the populations.

Table 3. AMOVA of populations

\begin{tabular}{llllll}
\hline Source & Df & SS & MS & Est. Var. & $\%$ \\
\hline Among populations & 3 & 205.09 & 68.36 & 0.95 & 4 \\
Within populations & 196 & 4437.47 & 22.64 & 22.64 & 96 \\
Total & 199 & 4642.56 & & 23.64 & 100 \\
\hline
\end{tabular}

\subsection{Gene Flow (Nm) between Populations}

Table 4 shows the gene flow $(\mathrm{Nm})$ between the Nigerian goat populations. The gene flow $(\mathrm{Nm})$ represents the number of migrants exchanged per generation. It ranged from 0.31 to 13.59. The highest gene flow was observed between Red Sokoto and Kano Brown population (13.59) while the least was between Sahel and West African Dwarf (0.31). 
Table 4. Gene flow between populations

\begin{tabular}{lll}
\hline Population 1 & Population 2 & Gene Flow (Nm) \\
\hline Red Sokoto & Kano Brown & 13.59 \\
Red Sokoto & Sahel & 5.78 \\
Kano Brown & Sahel & 8.26 \\
Red Sokoto & West African Dwarf & 3.96 \\
Kano Brown & West African Dwarf & 4.21 \\
Sahel & West African Dwarf & 0.31 \\
\hline
\end{tabular}

\subsection{Principal Component Analysis (PCA)}

The results of the PCA of the allele frequency data of the Nigerian indigenous goat populations using 25 microsatellite markers are shown in Figure 1. The PCA method was performed to further investigate possible genetic relationships between the Nigerian goat breeds. The first principal component (PC1) explains 31.04\% of the observed genetic variation and the second principal component (PC2) resolved $19.06 \%$ of the observed variation, which adds up to $50.1 \%$. This result showed that the Nigerian indigenous breeds are admixed and there are no distinct clusters on the basis of geographical regions where the goats were sampled.

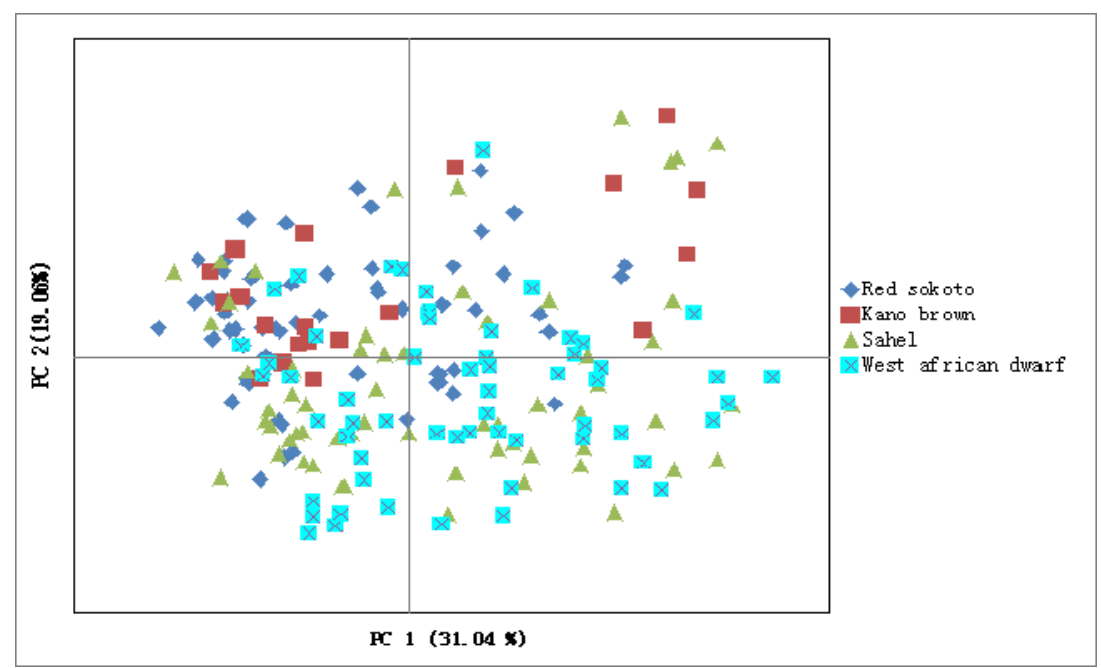

Figure 1. Two-dimensional graph representing the relationship between PC1 and PC2 using allele frequency data from 25 micro-satellite loci typed in 4 Nigerian goat populations

\subsection{Evano Graph of Nigerian Goat Population Structure}

An Evano graph in Figure 2 was plotted to detect the genetic structure of the Nigerian indigenous goat populations, as well as to determine the true number of clusters $(\mathrm{k})$ for this population, the value with highest mode (Delta $\mathrm{k}$ ) is usually an indication of the true number of clusters. From the graph in Figure 2, the variability among the population ranged from $\mathrm{k}=2$ to $\mathrm{k}=5$. The highest likelihood was observed at $\mathrm{k}=2$, implying that the Nigerian indigenous goat populations have two major locations in the country. 


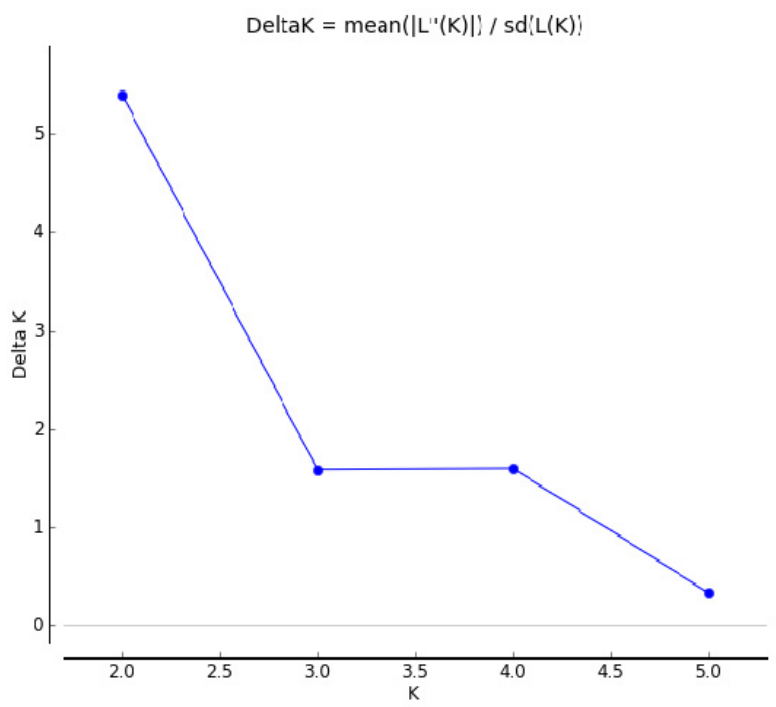

Figure 2. Evano graph of Nigerian goat population

\subsection{Estimated Population Structure among the Nigerian Goat Breed}

The estimated population structure among individual population is shown in Figure 3. Each individual was represented by a vertical line, which was partitioned into colored segments with the length of each segment representing the proportion of the individual's genome from $\mathrm{K}=2$, to $\mathrm{K}=6$. The first level of clustering $(\mathrm{K}=2)$ reflected the primary locations of the Nigerian indigenous goats namely Northern and Southern Nigeria. There was a distinct cluster at this level, which is consistent with the known locations of the goat populations in Nigeria. Subsequent levels $(K=3$ to $K=6)$ clearly showed signatures of admixture of the goats used in this study.

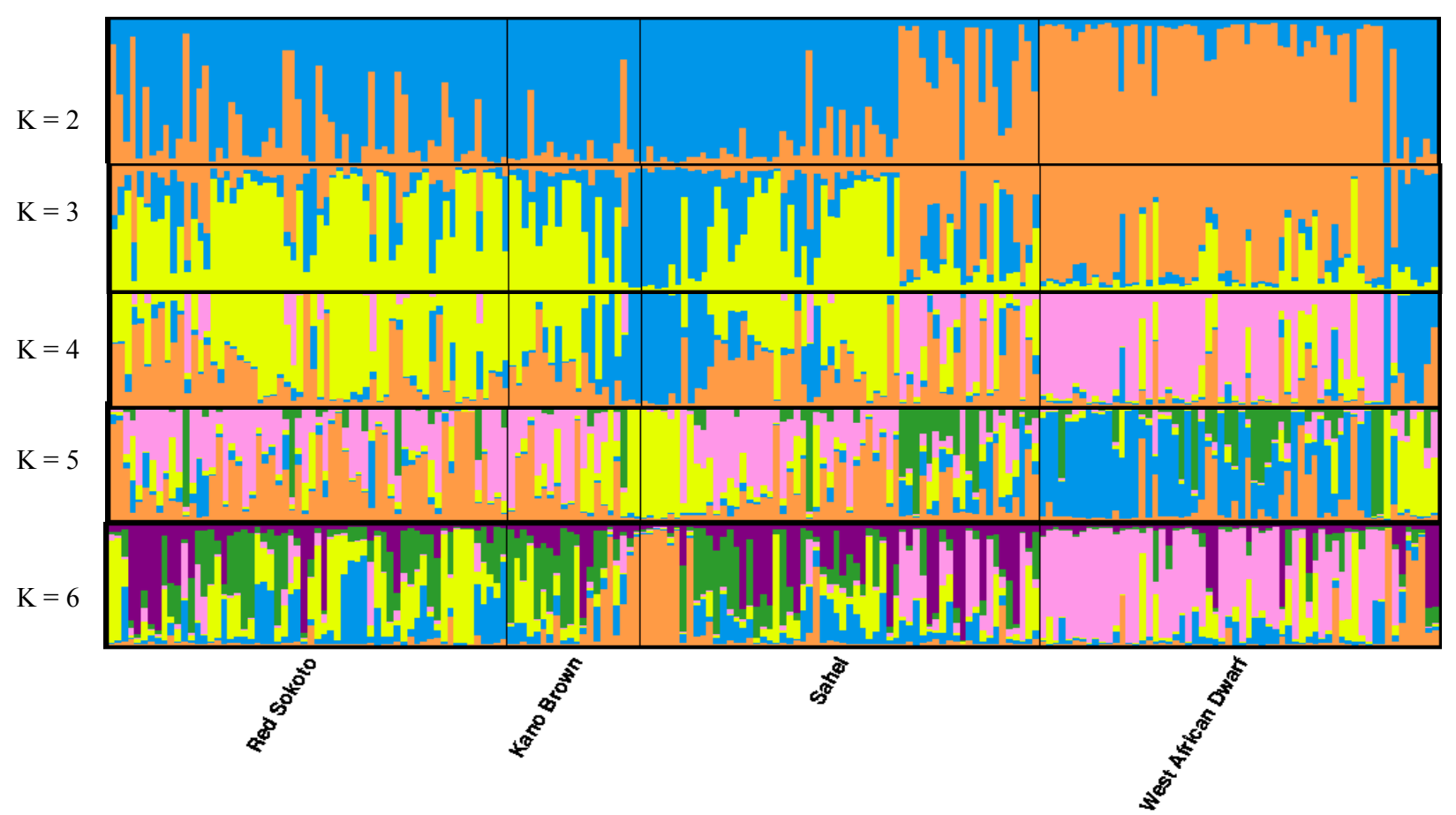

Figure 3. Estimated population structure of the Nigerian goat population 


\section{Discussions}

The low genetic differentiation between the goat populations in this study mainly resulted from migration and considerable exchange of genetic material among populations. This confirms that the Nigerian goat populations are not genetically distinct but are related to one another. Okpeku et al. (2011) obtained low to moderate $\mathrm{F}_{\mathrm{st}}$ values (0.048-0.191) for Sahel, Red Sokoto and West African Dwarf goats of Nigeria. However, higher estimates were obtained (0.056) for Chinese indigenous goats (Ling et al., 2012), (0.069) for the European and Middle Eastern goats (Cannon et al., 2006) and (0.143) for Southeast Asian goats (Barker et al., 2001). These variations in genetic differentiation may have resulted from population and breed differences.

Molecular genetic variation was observed to be higher within populations (96\%) than among populations (4\%), which suggest higher heterozygosity within population samples. These results were quite higher than those reported by Okpeku et al. (2011) who obtained (71\%) variation within populations and (29\%) variation amongst populations of West African Dwarf, Sahel and Red Sokoto goats of Nigeria. However, Rout et al. (2008) obtained $93.41 \%$ variation within populations and $6.59 \%$ variation among populations of Indian domestic goats, while between breed variation in Swiss goats was 17\% (MacHugh et al., 1998) using microsatellites. Similarly, Luikart et al. (2001) reported 10.7\% variation among goat breeds from Africa, Middle East, Asia and Europe. According to Toro and Maki-Tanila (2007), the high genetic diversity observed within population groups may have arisen from overlapping generations with natural selection favoring heterozygosity and the absence of artificial selection. Agha et al. (2008) reported that the effect of these factors is more pronounced when the effective population size is very large.

The high gene flow between Red Sokoto and Kano Brown (13.59) may have resulted from minimal reproductive isolation. This further supports proximal interbreeding leading to weakly identified phenotypic features and genetic similarities between the neighbouring breeds (Muhammed et al., 2010).

However, the low gene flow (3.96) between Red Sokoto and West African Dwarf may have resulted from minimal effects of migration and genetic drift as such, implying a larger reproductive isolation exists between the Red Sokoto and West African Dwarf goats. Distant geographic regions between these breeds may have contributed to this low gene flow (Okpeku et al., 2011).

The two dimensional scatter plot of the Principal component analysis showed that there were no distinct clusters for the Nigerian goat population. The admixture obtained in the Principal component analysis suggests that many of the sampled animals were not pure breeds but cross breeds. This might have resulted from indiscriminate mating and genetic drift amongst the breeds.

From the Evano graph, the statistic Delta $\mathrm{K}$ peaked at $\mathrm{K}=2$ indicating support for two groups. This implies that the Nigerian indigenous goat breeds are geographically distributed in two major locations namely; North and Southern Nigeria.

The results of Structure analysis confirmed that the Nigerian goat populations are not genetically differentiated and that there was some admixture within the Nigerian goat populations which might have resulted from indiscriminate mating, crossbreeding as well as migration between breeds. This admixture is expected as herds men migrate freely with their goats from North to Southwestern Nigeria in search of better vegetation and more economic returns from the sale of their stock.

\section{Conclusion}

In conclusion, this study has shown that microsatellite markers can be used to assess diversity in the Nigerian goat populations and the genetic differences among the Nigerian indigenous goats were low. The Evano- graph grouped the goats of Nigeria according to their geographic locations of origin indicating that the goats are geographically distributed in two major locations in Nigeria (North and South). The Principal component analysis and Structure confirmed that the Nigerian indigenous goat populations are not genetically differentiated but are admixed.

\section{Recommendations}

Measures to conserve uniqueness/distinctness of the Nigerian goat populations such as in-situ and ex-situ conservation should be sought. Appropriate breeding policies and strategies should be developed and adopted to improve the Nigerian indigenous goat populations. 


\section{References}

Agha, S. H., Pilla, F., Galal, S., Shaat, I., D’Andrea, M., Reale, S., Li, M. H. (2008). Genetic diversity in Egyptian and Italian goat breeds measured with microsatellite polymorphism. Journal of Animal Breeding and Genetics, 125, 194-200. http://dx.doi.org/10.1111/j.1439-0388.2008.00730.x

Akpa, G. N., Ifut, O. J., \& Mohammed, F. (2002). Indigenous management of dystocia in ruminant livestock of Nothern Guinea Savannah of Nigeria. Nigerian Journal of Animal production, 29(2), 264-270.

Barker, J. S. F., Tan, S. G., Moore, S. S., Mukherjee, T. K., Matheson, J. L., \& Selvaraj, O. S. (2001). Genetic variation within and relationships among populations of Asian goats. Journal of Animal Breeding and Genetics, 118(4), 213-233. http://dx.doi.org/10.1046/j.1439-0388.2001.00296.x

Cadmus, S. I. B., Adesokan, H. K., \& Awosanya, A. E. J. (2008). Public health issues and observations made during meat inspection at Bodija Municipal Abattoir, Ibadan, Oyo State Nigeria. Nigerian Veterinary Journal, 29(2), 43-47.

Canon, J., Garcia, D., Garcia-Atance, M. A., Obexer-Ruff, G., Lenstra, J. A., Ajmone-Marsan, P., Dunner, S. (2006). Geographical partitioning of goat diversity in Europe and Middle East. Animal Genetics, 37(4), 327-334. http://dx.doi.org/10.1111/j.1365-2052.2006.01461.x

FAO (Food and Agricultural Organization of the United Nations). (2011). FAO Stat. Retrieved July 19, 2011, from http://faostat.fao.org/default.aspx

Frankham, R., Ballou, J. D., \& Briscoe, D. A. (2002). Introduction to Conservation Genetics. Cambridge: Cambridge University Press. http://dx.doi.org/10.1017/CBO9780511808999

Hartl, D. (1980). Principles of population genetics (pp. 164-165). Sunderland, MA: Sinauer Association Inc, Massachusset, USA.

Ibrahim, S., Cadmus, S. I. B., Umoh, J. U., Ajogi, I., Farouk, U. M., Abubakar, U. B., \& Kudi, A. C. (2012). Tuberculosis in Humans and Cattle in Jigawa State, Nigeria: Risk Factors Analysis. Veterinary Medicine International (p. 5). http://dx.doi.org/10.1155/2012/865924

Issa, F. O., Iyiola-Tunji, A. O., Arokoyo, J. O., Aregbe, B. E., \& Owolabi, J. O. (2011). Evaluation of the challenge of climate change to commercial poultry egg production in Zaria, Kaduna state. Savannah Journal of Agriculture, 6(1), 75-84.

Ling, Y. H., Zhang, X. D., Yao, N., Ding, J. P., Chen, H. Q., Zhang, Z. J., ... Zhang, X. R. (2012). Genetic Differentiation of Chinese indigenous meat goats ascertained using Microsatellite Information. Asian-Australas Journal of Animal Science, 25(2), 1777-182. http://dx.doi.org/10.5713/ajas.2011.11308

Luikart, G., Gielly, L., Excoffier, L., Vigne, J. D., Bouvet, J., \& Taberlet, P. (2001). Multiple maternal origins and weak phylogeographic structure in domestic goats. Proceedings of Natural Academic Sciences, USA, 98(10), 5927-32. http://dx.doi.org/10.1073/pnas.091591198

MacHugh, D. E., Loftus, R. T., Cunningham, P., \& Bradley, D. G. (1998). Genetic structure of seven European Cattle breeds assessed using 20 microsatellite Markers. Animal Genetics, 299, 333-340. http://dx.doi.org/10.1046/j.1365-2052.1998.295330.x

Okpeku, M., Peters, S. O., Ozoje, M. O., Adebambo, O. A., Agaviezor, B. O., O’Neill, M. J., \& Imumorin, I. G. (2011). Preliminary analysis of microsatellite-based genetic diversity of goats in Southern Nigeria. Animal Genetic Resources, 49, 33-41. http://dx.doi.org/10.1017/S207863361100035X

Peakall, R., \& Smouse, P. E. (2012). GenAlex 6.5 genetic analysis in Excel, genetic software for teaching andresearch an update. Bioinformatics, 28, 2537-2539. http://dx.doi.org/10.1093/bioinformatics/bts460

Pritchard, J. K., Stephens, M., \& Donnelly, P. (2000). Inference of population structure using multilocus genotype data. Genetics, 155(2), 945-959.

Rout, P. K., Joshi, M. B., Mandal, A., Laloe, D., Singh, L., \& Thangaraj, K. (2008). Microsatellite based phylogeny of Indian domestic goats. BMC Genetics, 9(11). http://dx.doi.org/10.1186/1471-2156-9-11

Toro, M., \& Maki-Tanila, A. (2007). Genomics reveals domestication history and facilitates breed development. In K. Oldenbroek (Ed.), Utilization and conservation of farm animal genetic resources (pp. 75-102). Wageningen the Netherlands, Wageningen Academic Publishers.

Willi, Y., Buskirk, J., \& Hoffmann, A. A. (2006). Limits to the adaptive potential of small populations. The Annual Review of Ecology, Evaluation and Systematic, 37, 433-458. 
http://dx.doi.org/10.1146/annurev.ecolsys.37.091305.110145

Woolliams, J., Berg, P., Mäki-Tanila, A., Meuwissen, T., \& Fimland, E. (2005). Sustainable Management of Animal Genetic Resources (No. 5, pp. 46-49). Nordic Gene Bank Farm Animals, Nordisk Genbank Husdyr.

\section{Copyrights}

Copyright for this article is retained by the author(s), with first publication rights granted to the journal.

This is an open-access article distributed under the terms and conditions of the Creative Commons Attribution license (http://creativecommons.org/licenses/by/3.0/). 